\title{
NOTE
}

\section{Species number-area relationship in the deep sea}

\author{
R. L. Haedrich \\ Newfoundland Institute for Cold Ocean Science, Memorial University of Newfoundland, St. John's, Newfoundland A1B 3X7, Canada
}

ABSTRACT: Data on megafaunal species numbers and areas of faunal zones in the deep sea do not fit predictions of the species number-area relationship. This apparently anomalous situation can be resolved if food availability is taken into account. As theory would predict, the slope of the relationship for benthic megafauna $(0.36)$ is steeper than that for mesopelagic fishes $(0.13)$.

Theoretical background. The species-area relationship argues that species number should be a simple and direct function of the extent of the geographical area occupied by a fauna. This relationship has been found to hold in numerous situations, and over wide ranges of taxa and scales of species numbers and areas (Connor \& McCoy 1979). Cast into model form by a consideration of extinction and colonisation rates on islands (MacArthur \& Wilson 1967), the species-area relationship is usually expressed by the power function

$$
\mathrm{S}=\mathrm{kA}^{z}
$$

or by

$$
\log \mathrm{S}=\mathrm{z} \log \mathrm{A}+\mathrm{k}
$$

where $\mathrm{S}=$ number of species; $\mathrm{A}=$ area; $\mathrm{k}$ and $\mathrm{z}=$ fitted constants. In addressing the criticism that underlying assumptions of the theory had not been rigorously demonstrated, Wilcox (1978) showed that the time span of isolation could also enter the equation, but that area continued to play a major role.

A number of hypotheses have been advanced to explain the underlying basis of the species-area relationship. These include the original extinction/colonisation equilibrium theory (MacArthur \& Wilson 1963), an artifactual 'passive sampling' hypothesis whereby greater area simply collects more species over time (Connor \& McCoy 1979), and the idea that habitat diversity is the important factor and that this is positively correlated with area. Eadie et al. (1985) provide data that support the latter view, but the question remains unresolved.
Nonetheless, empirical evidence strongly supports the existence of a species number-area relationship. Since it appears well-established, the relationship has found its way into theoretical arguments. Contractions in area available to shallow-water marine faunas have been called upon to explain dramatic extinctions in past eras (Simberloff 1974, Flessa \& Sepkoski 1978), and it has been argued that the species-area relationship provides a simple explanation of the latitudinal gradient in species number (Osman \& Whitlatch 1978 , Schopf et al. 1977).

The species-area relationship has been suggested to apply in the deep sea (Abele \& Walters 1979), but this has not been tested. Rex (1981) attempted to look for such a relationship, but could not find one. In his brief analysis, however, he used areas arbitrarily defined according to topography, and not ones that were recognised as faunally discrete. In fact, data to examine the question of the species-area relationship in the deep sea have not been available.

Observations and discussion. Using information from a fully analyzed data set on megafauna from the continental slope and rise in the New York Bight (Haedrich et al. 1980) the species number-area relationship is plotted in Fig. $1 . \mathrm{S}$ is the total number of megafaunal species found in each of 8 discrete faunal zones (the shallowest is the continental shelf where $S$ is estimated to be about 210: Haedrich 1983) and A is vertical extent of zone divided by sine of slope (depth gradient) within each zone (Table 1). Unit width is assumed, and $\mathrm{A}$ is an index of actual area occupied.

There is no direct positive relationship. If only the deep ocean values are considered, the relationship is negative (Fig. 1). By the species number-area model, the deep ocean is a region of anomalously low diversity, with many fewer species than considerations of area would predict.

Can this result be reconciled with the many in- 


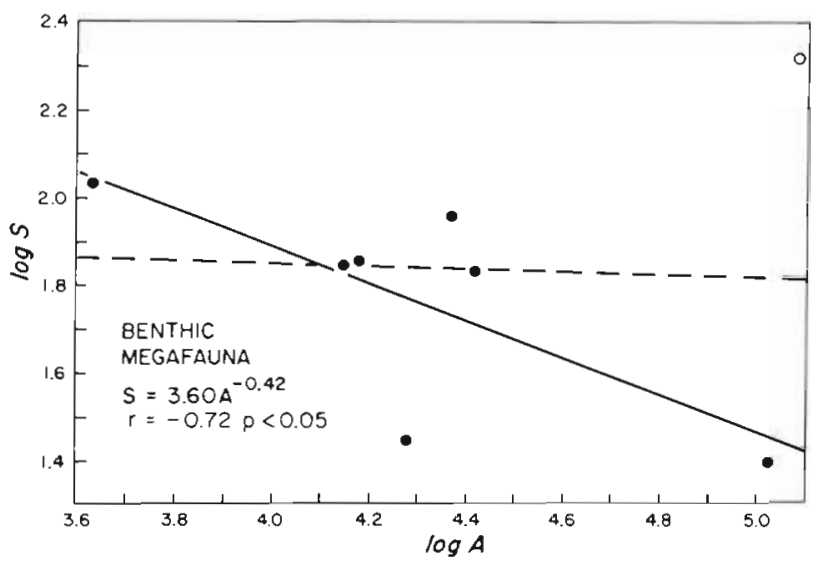

Fig. 1. Species number-area relationship for deep benthic megafauna in the New York Bight. Dashed line: regression for all points, not significant; solid line: regression for deep ocean points, shelf (open circle) excluded, significant with $r=-0.72$. Data from Table 1

stances reported which support the reality of the species number-area relationship? Let us take one of the oldest and simplest arguments relating to the underlying determinants of diversity: that greater food availability or production will promote greater numbers of species within an area (Connell \& Orias 1964). This concept has been criticised by Pianka (1966), among others, and is not held in high regard today. Nonetheless, the idea has recently been shown to hold in African rivers where discharge, and presumably the productivity of the drainage basin, is correlated with fish species number (Livingstone et al. 1982). It is likewise implicit in the correlations of catchment area with number of freshwater mussel species in southeastern U.S. rivers (Sepkoski \& Rex 1974). But even admitting this relationship, there is a very important distinction between essentially terrestrial situations and the deep sea. On land, where solar energy reaching the surface is reasonably uniform, production itself can be thought of as a function of area and should be roughly comparable over fairly broad regions. In the deep sea this is not so. Food input or availability declines exponentially as distance (depth) increases away from the productive surface layers (Carney et al. 1983), a fact which must be taken into account.

As a first approximation, assume that food availability in the deep sea tracks the biomass-depth relationship. For infauna collected in box cores from the New York Bight this is $\log B=1.44-0.29 \mathrm{Z}$ (Rowe \& Haedrich 1979). For $Z$ (depth, km) use the mid-point of each megafaunal zone to calculate approximate infaunal biomass $B$ in the zone. Because the dependence of the megafauna on infauna for food is not wellestablished, B must be considered an index. Multiply this index value by the area to give a new factor, $A B$, which reflects food availability (Table 1 ). This number plotted against species number gives the species number-food/area relationship of Fig. 2, a positive one in keeping with expectations. The lower continental slope falls above the line; this is in accord with the general observation that species maxima occur at intermediate depths (Rex 1983) and suggests that the region should be considered an ecotone. Rex (1973) noted the low species diversity of macro- and megafauna at abyssal depths, and thought this might result in part from extremely low productivity. But even with the incorporation of a food factor, the relationship suggests that the abyssal plain contains far fewer species than it ought; it is species-poor.

How does the species-food/area model fit data for pelagic regions? When the number of myctophid (lanternfish) species in each of 19 faunal regions determined for the Atlantic Ocean (Backus et al. 1978) is plotted against the area of the faunal region (determined by planimetry) a positive relationship is obtained, but the correlation is poor $(r=0.35)$. No depth differences can apply here, for all the species live at comparable depths in the upper several hundred meters of the water column. But oceanic productivity varies over 3 orders of magnitude. If primary production estimates (Koblentz-Mishke et al. 1970) for

Table 1. Parameters used in the calculation of the megafaunal species number-area and species number-area $\times$ biomass relationships by depth zone in the New York Bight. Data from Haedrich et al. (1980)

\begin{tabular}{|c|c|c|c|c|c|c|c|c|c|}
\hline Zone & $\Delta \mathrm{Z}$ & Slope & $\frac{\mathrm{A}}{\text { (relative area) }}$ & $\log A$ & $\begin{array}{c}\mathrm{S} \\
\text { (number of } \\
\text { species) }\end{array}$ & $\log S$ & $\begin{array}{c}\bar{Z} \\
\text { mean } \\
\text { depth }(\mathrm{km})\end{array}$ & $\frac{\text { B }}{\text { (biomass) }}$ & $\begin{array}{c}\log \\
A B\end{array}$ \\
\hline $40-264 \mathrm{~m}$ & 224 & - & 120000 & 5.08 & 210 & 2.32 & .152 & 24.88 & 6.48 \\
\hline $283-650 \mathrm{~m}$ & 367 & $1.4^{\circ}$ & 15021.2 & 4.18 & 72 & 1.86 & .467 & 20.16 & 5.48 \\
\hline $653-1290 \mathrm{~m}$ & 637 & $1.4^{\circ}$ & 26072.2 & 4.42 & 68 & 1.83 & .972 & 14.39 & 5.57 \\
\hline $1380-1947 \mathrm{~m}$ & 567 & $7.6^{\circ}$ & 4287.1 & 3.63 & 108 & 2.03 & 1.664 & 9.07 & 4.76 \\
\hline $2116-2481 \mathrm{~m}$ & 365 & $1.5^{\circ}$ & 13943.6 & 4.14 & 70 & 1.85 & 2.299 & 5.93 & 5.07 \\
\hline $2504-3113 \mathrm{~m}$ & 609 & $1.5^{\circ}$ & 23264.7 & 4.37 & 91 & 1.96 & 2.808 & 4.22 & 5.21 \\
\hline $3244-3740 \mathrm{~m}$ & 496 & $1.5^{\circ}$ & 18948.0 & 4.28 & 28 & 1.45 & 3.492 & 2.67 & 4.70 \\
\hline $3879-4986 \mathrm{~m}$ & 1107 & $0.6^{\circ}$ & 105712.0 & 5.02 & 25 & .40 & 4.433 & 1.43 & 5.18 \\
\hline
\end{tabular}




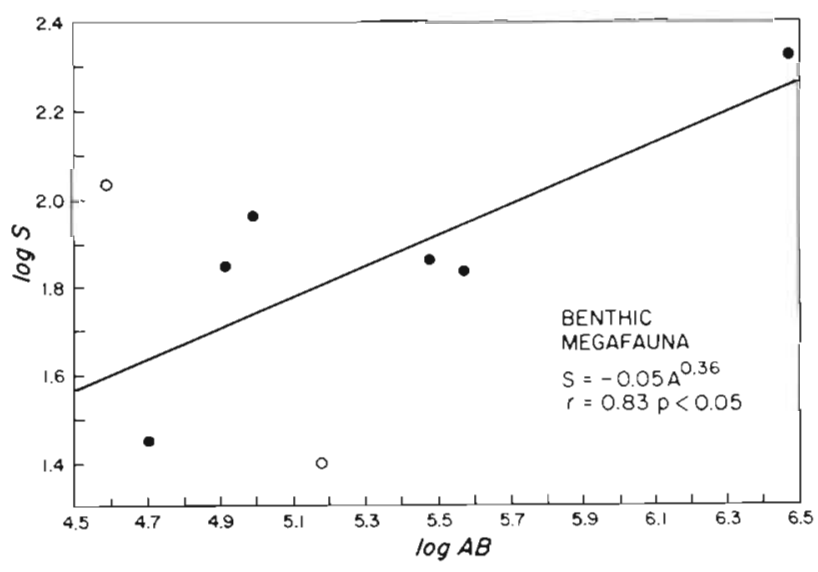

Fig. 2. Species number-area relationship for deep benthic megafauna with food availability taken into account. Regression for all points: $\mathrm{S}=0.47 \mathrm{~A}^{0.26}, \mathrm{r}=0.53, \mathrm{p} \sim 0.15$. Line is regression with ecotonal lower slope (upper open circle) and species-poor abyss (lower open circle) excluded, significant with $r=0.83$. Data from Table 1

each region are used to modify the estimate of area, an improved relationship results (Fig. 3). Three regions fall well below the line. These are eastern and western Mediterranean and the subarctic; all are isolated basins that have in all likelihood only recently been invaded and populated by midwater fishes. Were it possible to incorporate time into the relation, as Wilcox (1978) was able to do for lizard faunas on islands of known age, these points could be expected to fall into line.

Reported slopes (z) of the species-area relationship range between about 0.2 and 0.4 . The evolutionary/

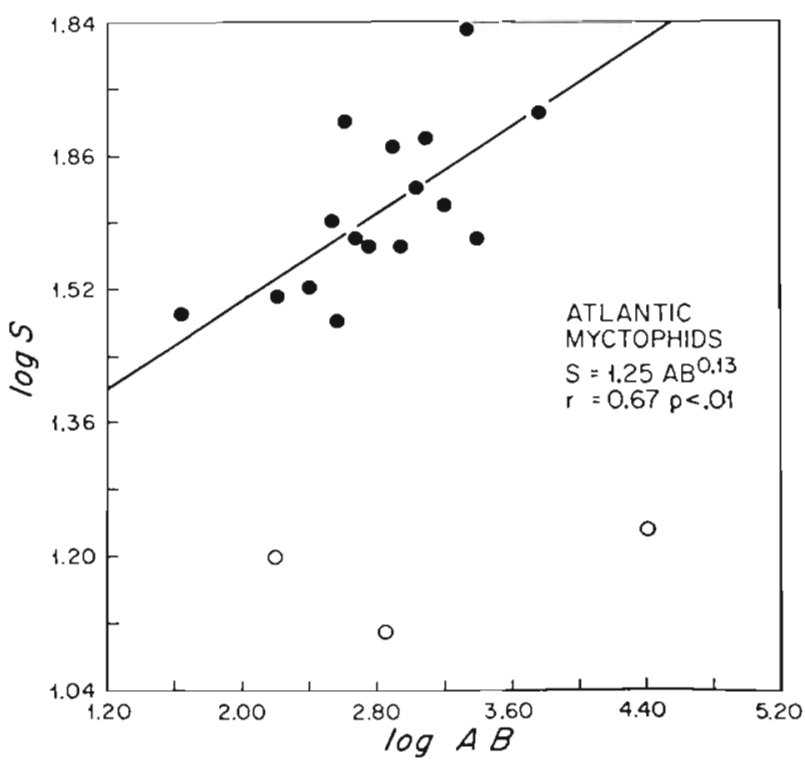

Fig. 3. Species number-area relationship for mesopelagic lanternfish with food availability taken into account. Line is regression with faunas of isolated basins(subarctic, eastern and western Mediterranean) excluded, significant with $r=0.67$ ecological significance of this value has been a matter of recurrent interest, despite the warning of Connor \& McCoy (1979) that the range could be merely an artifact of the regression. Nonetheless, there exists the expected decline in $\mathrm{z}$ with increasing taxonomic rank for orders vs families vs genera of mammals as a function of area on a worldwide basis (Flessa 1975), and Bronmark et al. (1984) could rationalize the difference between the low value of $z(0.19)$ for macroinvertebrates in Bornholm streams as compared to the high value (0.32) for mussels in U.S. rivers (Sepkoski \& Rex 1974) in terms of relatively greater dispersal and immigration rates. Barbour \& Brown (1974) had argued that when $\mathrm{z}=<0.16$, considerable homogeneity exists, little colonisation is taking place, and much time has elapsed. When $z=\gg 0.40$, then colonisation is a major factor and the flow of species from adjacent areas exceeds the extinction rate.

The interpretations of Barbour \& Brown (1974) would seem to fit the oceanic data. The slope of the relationship for benthic megafauna is much steeper than that for mesopelagic fishes. Mesopelagic faunas $(z=0.13)$ are old and phylogenetically distinct, and are uniform over most of the world ocean. Invasion by derived (i.e. perciform) fishes has not taken place to any extent. Continental slope faunas $(z=0.36)$ show considerable differences over rather small depth increases, and are different from place to place (Haedrich \& Maunder 1985). There is evidence that continued invasion of the deep sea by shallow-living species goes on (Haedrich \& Krefft 1976), and, furthermore, that species recruitment from onshore to offshore has been a major avenue of community development on the slope over evolutionary time (Jablonski et al. 1983).

Clearly more work needs to be done on deep ocean food supplies, particularly as regards the influence of rates on community structure. Results reported here based on the species-area relationship are not conclusive, and it is not intended that they be regarded as an unequivocal test. They raise the question of whether the areas that fall off the regression - the lower continental slope, abyss, and isolated basins of the pelagial - might have special characteristics that should be examined. And they do provide additional support for the view that energy is the prime ecological factor in the deep sea (Thiel 1980, p. 30).

Acknowledgements. Thanks are due to G. Brassard, J. A Hutchings, D. S. McKelvie, and G. R. South for their comments on the manuscript. The work was supported by grant A-7230 from the Natural Sciences and Engineering Research Council. 


\section{LITERATURE CITED}

Abele, L. G., Walters, K. (1979). Marine benthic diversity: a critique and alternative explanation. J. Biogeogr. 6 : 115-126

Backus, R. H., Craddock, J. E., Haedrich, R. L., Robison, B. (1978). Atlantic mesopelagic zoogeography. Mem. Sears Fdn mar. Res. 1, part 7: 266-286

Barbour, C. D., Brown, J. H. (1974). Fish species diversity in lakes. Am. Nat. 108: 473-489

Bronmark, C., Herrmann, J., Malmqvist, B., Otto, C., Sjostrom, P. (1984). Animal community structure as a function of stream size. Hydrobiologia 112: 73-79

Carney, R. C., Haedrich, R. L., Rowe, G. T. (1983). Zonation of fauna in the deep sea. In: Rowe, G. T. (ed.) Deep sea biology, Vol. 8, The sea. Wiley, New York, p. 371-398

Connell, J. H., Orias, E. (1964). The ecological regulation of species diversity. Am. Nat. 98: 399-414

Connor, E. F., McCoy, E. D. (1979). The statistics and biology of the species-area relationship. Am. Nat. 113: 791-833

Eadie, J. M., Hurly, T. A., Montgomerie, R. D., Teather, K. L. (1985). Lakes and rivers as islands: species-area relationships in the fish faunas of Ontario. Environ. Biol. Fish. (in press)

Flessa, K. W. (1975). Area, continental drift and mammalian diversity. Paleobiology 1: 189-194

Flessa, K. W., Sepkoski, J. J., Jr. (1978). On the relationship between Phanerozoic diversity and changes in habitable area. Paleobiology 4 : 359-366

Haedrich, R. L. (1983). Estuarine fishes. In: Ketchum, B. H. (ed.) Ecosystems of the world, Vol. 22, Estuaries and enclosed seas. Elsevier, Amsterdam, p. 183-207

Haedrich, R. L., Krefft, G. (1976). Distribution of bottom fishes in the Denmark Strait and Irminger Sea. Deep Sea Res. 25: 705-720

Haedrich, R. L., Maunder, J. E. (1985). The echinoderm fauna of the Newfoundland continental slope. Proc. 5th Int. Echinoderm Conf., Galway, Sept. 1984. Balkema, Rotterdam (in press)

Haedrich, R. L., Rowe, G. T., Polloni, P. T. (1980). The megabenthic fauna in the deep sea south of New England, USA. Mar. Biol. 57: 165-179

Jablonski, D., Sepkoski, J. J., Jr., Bottjer, D. J., Sheehan, P. M.
(1983). Onshore-offshore patterns in the evolution of phanerozoic shelf communities. Science 222: 1123-1125

Koblentz-Mishke, O. J., Volkovinsky, V. V., Kabanova, J. G. (1970). Plankton primary productivity of the world ocean. Symp. Sc1. Explor. S. Pacific, Nat. Acad. Sci. Washington, p. $183-193$

Livingstone, D. A., Rowland, M., Bailey, P. E. (1982). On the size of African riverine fish faunas. Am. Zool. 22: 361-369

MacArthur, R. H., Wilson, E. O. (1963). An equilibrium theory of insular zoogeography. Evolution 17: 373-387

Osman, R. W., Whitlatch, R. B. (1978). Patterns of species diversity: fact or artifact? Paleobiology 4: 41-54

Pianka, E. R. (1966). Latitudinal gradients in species diversity: a review of concepts. Am. Nat. 100: 33-46

Rex, M. A. (1973). Deep-sea species diversity: decreased gastropod diversity at abyssal depths. Science 181: 1051-1053

Rex, M. A. (1981). Community structure in the deep-sea benthos. Ann. Rev. Ecol. Syst. 12: 331-353

Rex, M. A. (1983). Geographic patterns of species diversity in the deep-sea benthos. In: Rowe, G. T. (ed.) Deep sea biology, Vol. 8, The sea. Wiley, New York, p. 453-472

Rowe, G. T., Haedrich, R. L. (1979). The biota and biological processes on the continental slope. In: Pilkey, O., Doyle, L. (ed.) Continental Slopes. Society of Economic Petrologists and Mineralogists, Spec. Pub. no. 27, Tulsa, p. 49-59

Schopf, T. J. M., Fisher, J. B., Smith, C. A. F., Jr. (1977). Is the marine latitudinal diversity gradient merely another example of the species-area curve? In: Battaglia, B., Beardmore, J. A. (ed.) Marine organisms, genetics, ecology, and evolution. Plenum, New York, p. 365-386

Sepkoski, J. J., Rex, M. A. (1974). Distribution of freshwater mussels: coastal rivers as biogeographic islands. Syst. Zool. 23: $165-188$

Simberloff, D. S. (1974). Permo-triassic extinctions: effects of area on biotic equilibrium. J. Geol. 82: 267-274

Thiel, Hj. (1980). Structural aspects of the deep-sea benthos. Ambio Spec. Rept. no. 6: 25-31

Wilcox, B. A. (1978). Supersaturated island faunas: a speciesage relationship for lizards on post-pleistocene landbridge islands. Science 199: 996-998

Accepted for printing on April 22, 1985 